\title{
Influence of the Septuagint on the Typological Interpretation of Joshua and His Deeds in Justin Martyr's "Dialogue with Trypho, the Jew"
}

\author{
LESZEK MISIARCZYK \\ Cardinal Stefan Wyszyński University, Warsaw \\ I.misiarczyk@uksw.edu.pl ORCID: 0000-0002-9511-6174
}

\begin{abstract}
The aim of the article is to argue that the typological interpretation of Joshua and his actions in the Dialogue with Trypho, the Jew by Justin the Martyr, was only possible thanks to the Hellenized version of the Old Testament known as the Septuagint. In the Introduction, it was synthetically recalled that Justin in Dialogue argues with Marcionism and Judaism, and in Part 1 the status of the Septuagint was recalled in Judaism and ancient Christianity, as well as his methods of interpreting the Old Testament. In Part 2, the author concentrates on the analysis of the relevant fragments of the Dialogue in which there is a typological interpretation of Joshua and his actions. The influence of the Septuagint on

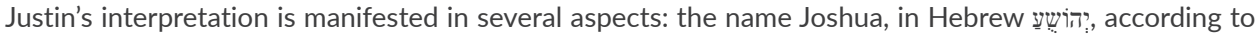
the Septuagint, sounds exactly the same as the name of Jesus Christ Inooũ and is the basis for the presentation of Joshua as a type of Christ; the second circumcision of the Israelites by Joshua, with stone knives, after entering the Promised Land was a type and foreshadowing of the spiritual circumcision of the Gentile heart by Jesus Christ from stones, that is pagan deities and the error of the world; the blood of circumcision at Gilgal was a type of the blood of Christs; stone knives ( $\mu a x a i p a \varsigma \pi \varepsilon t \rho i v a c)$ were a type of the teaching and words of Christ with which he circumcises the hearts of the pagans; the heap of twelve stones was a type of many heathens circumcised from the false polytheism. And the mention of this second circumcision, which Justin interprets as a type of real spiritual circumcision made by Christ, shows us the Dialogue as the oldest testimony of the Septuagint version confirmed by the Code of Alex-

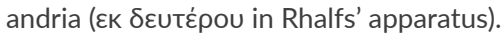

Keywords: Septuagint, typology, Joshua, Justin Martyr

As we know, Justin's Dialogue was written approx. AD 164 and contains a testimony of the struggle of the young Church with the internal threats such as Marcionism and Gnosticism, as well as the external ones such as pagan polytheism, Hellenistic philosophy and Judaism. ${ }^{1}$ Since the polemic with the pagan world and Hellenistic philosophy does not fall within the scope of this study, it will be omitted in further considerations, ${ }^{2}$ and I will focus solely on Marcionism and Judaism.

Cf. Misiarczyk, Il Midrash, 5-27; Misiarczyk, “Wstęp," 123-150.

2 The literature on this subject is very rich and I refer to it - cf. Daniélou, Message évangelique; Misiarczyk, "Apologetyka wczesnochrześcijańska," 15-48; Jaeger, Wczesne chrześcijaństwo; Cantalamessa, "Cristianesimo primitivo," 26-57; Joly, Christianisme et philosophie, 85-128; Bourgeois, La sagesse des anciens, 26ff; Schmid, Frühe Apologetik und Platonismu; Hyldahl, Philosophie und Christentum; Van den Winden, An Early Chris- 


\section{LESZEK MISIARCZYK}

Justin, as the first early Christian author, argued with the Gnostic vision of salvation history in his treatise Against Marcion, which, unfortunately, has not survived to our times, but he also did it in the 1st Apology and Dialogue. The apologist criticized harshly both Marcion's dualism in the perception of God and his rejection of the Old Testament as worthless for Christians, in addition to some elements in the New Testament, being too Jewish in his opinion, such as e.g., Gospel of Matthew. These two elements only seemingly do not have anything in common as, actually, the latter results from the former. By acknowledging the existence of two gods: the inclement God of the Old Testament and the merciful God, the Father of Jesus Christ, Marcion rejected the Old Testament as a revelation of the inclement God of the Jews, thus questioning the continuity of the history of salvation. In response to these arguments, Justin argued that there is only one true God, the Creator of the universe, cognizable by human reason and described by Hellenistic philosophy, identical with the God of the patriarchs and the Father of Jesus Christ. Consequently, there is only one economy of salvation, which involves both philosophy, the Old and New Testaments, and its center is Jesus the Messiah, the Son of God. He definitely defended the historical and salvific meaning of the Old Testament by applying to its interpretation, inter alia, the so-called proof from prophecy and the typological method. ${ }^{3}$

While the polemic with Marcionism concerned the value of the Old Testament for Christians in general, the discussion with Judaism focused on the proper understanding of the events, people and prophecies conveyed therein. Justin devoted his Dialogue with Trypho the Jew to this subject, in which, by developing the teaching of St Paul he sees the persons and events of the Old Testament as foreshadowing the reality that has been fully revealed in Christ. Thus, Old Testament revelation, as he continuously repeats in his conversation with Trypho, have a sense to him only when it is read from the perspective of Christ and not per se. Believing in Jesus as the Messiah and Son of God and the interpretation of the Old Testament from the perspective of this faith will become the axis of a heated dispute between the followers of Judaism and Christ's disciples, beginning in the first century AD and extending over the centuries to follow. Justin's Dialogue is part of a long-lasting discussion between scholars about the historicity of the real dispute between Christianity and Judaism in the period from the first to the end of the third century AD. Some researchers question the reality of such a confrontation in the second century, as

tian Philosopher; Goodenough, The Theology of Justin Martyr; Vogel, Problems Concerning Justin Martyr, 360-388; Chadwick, Justin Martyr's Defense of Christianity, 275-297; Chadwick, Early Christian Thought; Barnard, Justin Martyr; Skarsaune, "The Conversion of Justin Martyr," 53-73; Andresen, "Justin und der mittlere Platonismus," 157-195; Holte, "Logos Spermatikos," 109-168; des Places, "Platonisme moyen," 432-441; Pycke, "Connaissaince rationnelle," 52-85; Misiarczyk, "Wstęp," 124-135; Karłowicz, Socrates, 56-68.

3 Cf. Misiarczyk, "Wstęp," 135-140. 
evidenced by the lack of parallel anti-Christian Jewish literature. ${ }^{4}$ As a consequence, they undermine both the historicity of Trypho's existence and his dispute with Justin in Ephesus. Moreover, they perceive the Dialogue itself as a pure literary fiction, the purpose of which would be merely to arouse anti-Semitism among pagan Christians or to warn the catechumens against the Jews. ${ }^{5}$ From this perspective, the Dialogue would obviously not be addressed to Jews to answer their objections or to persuade them to convert to Christianity. A much larger group of researchers, however, is of the opinion that the relationship between Christianity and Judaism in the second century was marked by a real conflict, ${ }^{6}$ which seems to be confirmed by the continued attractiveness of Judaism to Christians with pagan descent and the success of Jewish propaganda both in this period and later. ${ }^{7}$ Set in the context of the real and historical confrontation between Christianity and Judaism Justin's Dialogue appears as a real historical dispute written later by himself or someone from his circle and elaborated in a more systematic way. ${ }^{8}$ The Dialogue is therefore historical in such a way that it is based on a real dispute worked out successively by Justin himself or his disciples, but it is certainly not an accurate word-for-word recording of an earlier discussion. ${ }^{9}$ The addressees of the clearly anti-Judaic parts of the work, in which Jews are portrayed as enemies of Christianity who are not to be discussed with, would be Christians of Jewish origin or iudaizantes. And these parts of Justin's work clearly fit in the theme Christian literature called Adversus Iudaeos. In turn, those fragments of the Dialogue in which the Apologist defends the Old Testament values for Christians of pagan descent would be clearly anti-Marcion, whereas the remaining fragments of the text would be addressed to all who seek the truth. ${ }^{10}$ Since the typological interpretation of Joshua in the Dialogue is clearly in line with the anti-Judaic polemic, in the next part I will focus only on this aspect of Justin's work, ignoring the dispute with marcionism. Since this interpretation is based on the ancient Greek translation of the Old Testament known as the Septuagint, before proceeding to the analysis of the relevant fragments of the Dialogue, it is

4 Cf. Harnack, Die «Altercatio Simonis Iudaei et Theophili christiani»; Harnack, Judentum und Judenchristentum; Tränkle, Q.S.F. Tertulliani Adversus Iudaeos, LXVI-LXXVIII.

5 Cf. Schneider, "Some Reflections," 164-175; Bokser, "Justin Martyr," 97-122, 204-211; Rokeah, Jews, Pagans and Christians; Nichols, Christian Antisemitism; Tylor, Anti-Judaism.

6 Cf. Simon, Verus Israel, 165-213. See also Stanton, "Aspects," 377-392.

7 See among others Herford, Christianity; Stern, Greek and Latin Authors; Barrett, "Jews and Judaizers," 220-224; Meeks - Wilken, Jews and Christians; Sanders, Jewish and Christian; Bokser, "Recent Developments," 1-68; Frend, "Early Christianity," 53-71; Santon, "Aspects," 377-392; Remus, "Justin Martyr's Argument," 59-80; Callan, Forgetting the Root; Radford Ruether, "The Adversus Judaeos," 174-189; Lieu et al., The Jews Among; Krauss, "The Jews," 219-230; Constantelos, "Jews and Judaism," 273-294; Setzer, Jewish Responses.

8 Cf. Barnard, Justin Martyr, 23ff; Otranto, Esegesi biblica, $235 f$.

9 For more on the historicity of the Dialogue see Misiarczyk, "Wstęp," 135-150.

10 Cf. Misiarczyk, "Wstęp," 135-150. 
worth, at least briefly, presenting its status in the Judaism of the era and the general exegetical methods employed by Justin in general.

\section{The Status of the Septuagint in Second Century Judaism and Christianity as well as Methods of Interpreting the Old Testament in the Dialogue}

The confrontation between Christianity and ancient Judaism referred to the understanding of the Old Testament and covered three areas: a discussion on the version of the Old Testament text itself, the question of its interpretation and, finally, the relevance of its reference to Christ. ${ }^{11}$ As for the quoted version of the Old Testament text, Justin, as he admits himself, uses the Septuagint most often, also defending its authority over new translations made by Jews (Dial. 71:1). He repeatedly emphasizes that the leaders of Judaism reject the translation of the Septuagint made for King Ptolemy (Dial. 67:7; 71:1; 84:3) because they believe it is inaccurate in some places (Dial. 68:7; 71:1; 84:3) and took the initiative to prepare a new translation into Greek (Dial. 84:3). ${ }^{12}$ We know from other sources that in the second century, there indeed appeared new Greek translations of the Old Testament Scriptures within Judaism, known as the translations of Aquila, Symmachus and Theodotion..$^{13}$ As far as the Septuagint is concerned, ancient Judaic sources are ambivalent in assessing this translation: e.g. the so-called Letter of Pseudo-Aristeas, texts of Philo, Josephus Flavius and some rabbinical texts (e.g. the treatise Megilloth 2:5 of the Babylonian Talmud) evaluate it positively, while other rabbinical sources, such as the treatise Megilloth 9a-b and Mekchilta of Rabbi Ishmael 14:65 emphasize that the ancient Greek translation of the Bible is inaccurate in many places. Researchers explain this ambivalence of rabbinical sources towards the Septuagint in two ways: one hypothesis seeks the reasons for its rejection by the leaders of Judaism in the adoption of this version of the Old Testament by Christians, while the other one emphasizes that a certain kind of resistance to this translation arose in Jewish communities at the time of its inception as an opposition to the Ptolemy's policy of Judaism Hellenization. ${ }^{14}$ Both hypotheses

11 Cf. Daniélou, Message évangelique; Skarsaune, The Proof from Prophecy; Simon, "La Bible," 107-125; Misiarczyk, "Wstęp," 153-157.

12 Justin is not entirely precise here, because only the Torah, i.e. the Jewish Law, was translated at Ptolemy's request, while other books of the Old Testament were translated later, but probably in his time the complete truthfulness of the Letter of Aristeas was believed and the entire translation of the Septuagint was attributed to the initiative of Ptolemy.

13 Cf. Fernández Marcos, The Septuagint in Context, 109-154.

14 See Veltri, Eine Tora, 15-18; Fernández Marcos, The Septuagint in Context, 18-102; see also various studies in: Cook - Stripp, Text-Critical and in: Bons - Pouchelle - Scialabba, The Vocabulary. 
are not mutually exclusive, since the old opposition to the Septuagint as a form of Hellenization of Judaism could have easily been radicalized, even leading to its rejection along with the Christian use of this version of the Old Testament in polemics with the believers of the Jewish religion. An additional element stems from the fact that the translation of the Septuagint provided a broader basis for the Christian interpretation of some texts and for demonstration that the prophetic announcements came true in Jesus of Nazareth, such as in the famous text of Isa 7:14. ${ }^{15}$ In the new translations of the Greek Bibles produced in the 2nd century, both the one of Aquilia that was referenced to by Justin in the Dialogue, and the later ones, i.e., the one of Symmachus (c. 165) and the one of Theodotion (c. 180), there is an evident tendency towards a more literal translation of the Old Testament and a distancing from the Septuagint as part of anti-Christian polemics. Of course, Justin quotes the text of the Old Testament in the Septuagint version, even more, as Dominique Barthélemy convincingly demonstrated in the case of the minor prophets, ${ }^{16}$ their Palestinian review and other versions made earlier than the known codices of this version that have survived to our time. ${ }^{17}$ Apart from the biblical texts, he also very often quotes different fragments of the Old Testament from the so-called Testimonia, i.e., collections of Old Testament texts collected according to themes or key terms treated by Christians or Judeo-Christians as dicta probantia, in which they saw the announcements of events fulfilled in the life and teachings of Christ. ${ }^{18}$ Over time, these collections of quotations must have gained great esteem among Christians, as they often became the foundation for introducing changes to the biblical text. The basis for such changes included exegetical methods borrowed from Judaism, such as targum or midrash, therefore one may suppose with a high probability that they were created very early in the Judeo-Christian environment. Justin, e.g., in Dial. 73:1, quotes a Targumic version of Ps 96:10 and provides many examples of Jewish traditions in which the midrash method was used, and he himself uses it for the Christian interpretation of the Old Testament. ${ }^{19}$

In addition to using the midrash or targum, Justin also uses two new methods of interpreting the Old Testament: the so-called proof of prophecy and typology. The former is a direct attribution of some Old Testament prophecy to Jesus as the promised Messiah. As a consequence, e.g., in his opinion, Isa 7:14 cannot refer to Hezekiah as he was not born of a virgin and the so-called theophanies in the Old Testament, are actually the revelation of the Logos which was revealed to Abraham under the oaks of Mamre, fought Jacob, was revealed to Moses in the burning bush, and walked in the lead of the Israelites from Egypt. Therefore, if the Scriptures speak of the revela-

\footnotetext{
See Misiarczyk, Il Midrash, 196-205.

Cf. Barthélemy, Les devanciers, 203-212.

See Smit Sibinga, The Old Testament.

Cf. Rendel Harris, Testimonies; Daniélou, Études d'exégèse.

See Misiarczyk, Il Midrash.
} 
tion of God, it cannot be God - the Creator of the world, but the so-called "second God," numerically different from the Creator. This "second God" is the Logos, which revealed Himself covertly in the Old Testament as God's messenger (angelos) and revealed Himself to the fullest in Jesus of Nazareth, being conceived and born by Virgin Mary. ${ }^{20}$ Therefore, all the Old Testament prophecies are entirely fulfilled in Christ.

Nevertheless, typology is the most frequently used method of the Christian interpretation of the Old Testament by Justin. This method goes beyond the historical and literal interpretation of the Old Testament, as did the Jews, and results in the recognition of events or persons described in it as types, that is, announcements of reality fulfilled in the life and actions of Christ and the Church. ${ }^{21}$ The adoption of such an approach in the interpretation of the Old Testament results in the classification of the events from the life of Jesus and the Church as real and most important for the history of salvation, whereas those historical Old Testament events or persons are assigned the rank of symbols, figures, shadows and announcements. Therefore, the key to an appropriate understanding of the Old Testament revelation is beyond it, and it is Christ. According to Justin, reality is superior to a figure or an announcement and is the reason for its existence, which explains why the Old Testament has no value on its own, but only has value as an announcement of the fullness of revelation in Christ. We find many similar typological interpretations in the Dialogue with Trypho: wood or Aaron's rod are a kind of a cross for Justin; a rock symbolizes Christ; Moses' raised hands in the fight against the Amalekites symbolize Christ on the cross and the name Joshua - Jesus and many others. In the center of Justin's theology of history is Christ, who fulfills God's economy of salvation announced in prophecies (in words) and events, as well as Old Testament persons (types). ${ }^{22}$ The Christ-centered interpretation of the Old Testament enables our author to directly refer the Old Testament prophecies to Christ; thanks to the use of typology, it also allows him to refer indirectly to events and people. The interpretation of Joshua being a type of Christ is one example of such a typology, which was only possible by the quotation of the Old Testament in the Septuagint version, as in the Hebrew text such a similarity is completely illegible. So, in the further part of the analysis, I will focus only on this interpretation.

\section{Joshua as a Type of Jesus Christ}

The first mention of Joshua appears in Dial. 24:2 during the analysis of the stone knife circumcision of the Israelites who had egressed from Egypt and were now to

\footnotetext{
20 Cf. Misiarczyk, Il Midrash.

21 Cf. Shotwell, The Biblical Exegesis.

22 Cf. Misiarczyk, "Teologia dziejów," 146-160.
} 
enter the Promised Land. In earlier chapters (21-23) Justin persuades his Jewish interlocutors that "it was by reason of your sins and the sins of your fathers that, among other precepts, God imposed upon you the observance of the Sabbath as a sign"23 "not because he needed such sacrifices." ${ }^{44} \mathrm{He}$ continues by arguing that physical circumcision cannot be the foundation of man's justification:

If we do not accept this conclusion, then we shall fall into absurd ideas, as the nonsense either that our God is not the same God who existed in the days of Enoch and all the others who were not circumcised in the flesh, and did not observe the Sabbaths and the other rites, since Moses only imposed them later; or that God does not wish each succeeding generation of humanity always to perform the same acts of righteousness. Either supposition is ridiculous and preposterous. ${ }^{25}$

If circumcision and abiding by Sabbath were absolutely essential for salvation as well as desired by God, how can one understand that in the times of Enoch and other patriarchs before Abraham, God did not demand them to be circumcised, and before Moses there was no command to observe the Sabbath? One would have to accept that the God of the patriarchs is not the same God of Abraham who ordered him to circumcise, or it is not the same God of Moses who imposed the Sabbath. Or one would have to assume that God did not always insist on the same justice for all people, and sometimes justified them on the basis of something else, and sometimes on the basis of circumcision and the observance of the Sabbath. According to Justin, circumcision and the Law of Moses were imposed because of human sins. Therefore, if circumcision was not required before Abraham, and the observance of Sabbath, celebrations and sacrifices was not essential before Moses, there is no need to do so now, after the birth of Jesus Christ, the Son of God from the house of Abraham (23:3). After all, Abraham was justified and blessed by God while he was still uncircumcised. The Scriptures confirm that he was circumcised as a sign of justification and not as its basis (cf. Gen 17:11; Rom 4:11), which is also proved by the fact that women cannot be circumcised and yet they gain justification. In this context, Joshua made reference to the circumcision of the Israelites after entering the Promised Land (Josh 5:2-3). Thus, on the one hand, as we knew, Justin points out following St Paul, that after the coming of Jesus, the Messiah, and the Son of God, circumcision is no longer a necessary condition for salvation of people because it is obtained through the faith in Christ. On the other hand, he presents a typological interpretation of circumcision performed by Joshua as a foreshadowing of true, spiritual circumcision performed by Christ. At the beginning of chapter 24, Justin announces that he could explain the symbolism of the eighth day, i.e., the Resurrection, which, even more

\footnotetext{
23 Justin, Dialogue 21,1 (Falls, 33).

24 Justin, Dialogue 22,1 (Falls, 34).

25 Justin, Dialogue 23,1 (Falls, 37).
} 


\section{LESZEK MISIARCZYK}

than the seventh day of Sabbath, conceals in itself a secret proclaimed by the Old Testament events, but in order to avoid accusations of straying from the subject, he returns to circumcision:

[...] understand what I now state, that the blood of circumcision is now abolished, and we now trust in the blood of salvation. Now another covenant, another Law has gone forth from Zion. Jesus Christ circumcises with knives of stone all those who want it, that they may become a righteous nation, a faithful, truthful, and peace-loving people. ${ }^{26}$

Let us focus on some important details from this text. Firstly, it is interesting that, when writing about circumcision, Justin does not refer to Gen 17, which mentions the first historical circumcision of Abraham; however, by using the phrase "with flint knives" he clearly alludes to the circumcision performed by Joshua. Obviously, it is not accidental since Joshua circumcised the sons of Israel who were born during the journey in the wilderness and were uncircumcised like their fathers, who came out of Egypt but died in the wilderness. Joshua, by command of God, circumcised the young Israelites so that they would not enter the land of promise as uncircumcised (Josh 5:2-3). Justin further states that the blood of the old circumcision lost its meaning ( of Christ that brings salvation. He explicitly opposes "the blood of circumcision" (

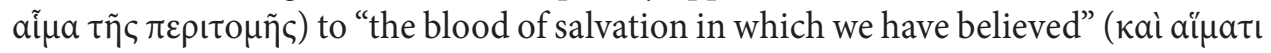

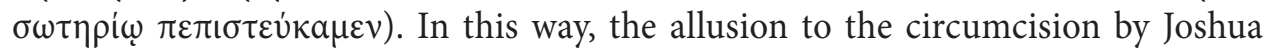
also becomes clear. Just like the blood coming from the circumcision performed by him near Gilgal allowed young Israelites to enter the land promised by God, so now the blood of Christ shed on the cross brings salvation and leads into the new promised land, i.e., the eternal life of those who believe in Him. It was in the blood of Christ that the new covenant announced by the prophets Isaiah 55:3 and Jeremiah 31:31 was made; and also from the new Christian Zion, a new spiritual law was created, which was also announced by the prophets Micah 4:2 and Isaiah 2:3. According to Justin, it is Jesus Christ who now performs true spiritual circumcision with flint

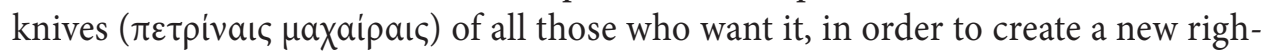
teous nation, a people guarding faith, holding fast to the truth and guarding peace. The circumcision performed by Joshua was, therefore, according to the Apologist, a type of true circumcision which is currently performed by Christ. In the context of the whole Dialogue, it is easy to notice that for Justin, this new circumcision that cleanses every human being is the sacrament of Baptism, which immerses one exactly in the blood of Christ and opens the gates of salvation. ${ }^{27}$ While it is understandable that Joshua circumcised the sons of Israel, as we read in the Hebrew text, with "flint knives" (הרְבוֹת צִרִים), as they were in use at that time, the statement of the exe-

26 Justin, Dialogue 24,1-2 (Falls, 38; Marcovich, 109).

27 Cf. Justin, Dialogue 12,3; 13,1-2; 19,1-6; 116; 128; 29,1-3; 45,14;87,1-5; 138,1-3. 
gete from Flavia Neapolis, whereby Christ performs a new circumcision with "flint

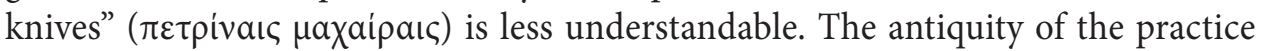
itself among the Jews is confirmed in Exod 4:25 when Zipporah just took a sharp flint piece and cut off her son's foreskin with it. But what did Justin mean by writing

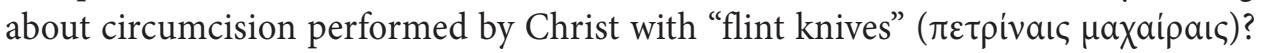
It is associated with the parallelism of the circumcision performed by Joshua, which

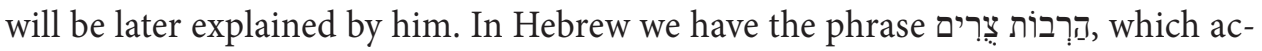
tually means "stone/flint knives," ${ }^{28}$ while the Septuagint conveys this with $\mu$ axaipas

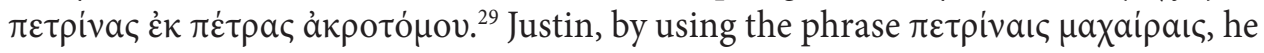
clearly refers to some version of the biblical text of the Septuagint other than that in the present critical edition by Rahlfs, because he shortens it, changes the word order and slightly modifies the form. Secondly, it was also due to the Septuagint that Justin linked the circumcision performed by Joshua with the new circumcision per-

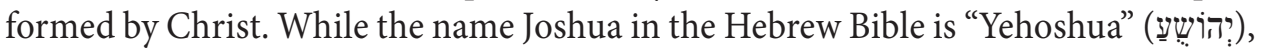
in the Septuagint it is translated as "Jesus" (Inбoṽs), which is exactly the same as the name of Jesus the Messiah in the Greek version of the Dialogue. Hence, it can be seen that in the above test, the influence of the Septuagint on Justin's typological interpretation of circumcision performed by Joshua is absolutely fundamental. It manifests itself in two ways: by using the same Greek name Inбoṽ for both Joshua

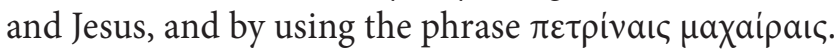

In Dial. 61:1; 62:5; 111:4, and 132:1 there is no typological interpretation of Joshua, but a reference to him as a historical person; however, it is worth taking a closer look at it, as Justin once again mentions the name of Joshua as it is in the Septuagint. In this part of the Dialogue, he focuses on arguing for the divinity of Jesus Christ, where, starting from chapter 59, he tries to prove the existence of this "other God" on the basis of Old Testament. In chapter 61:1, he wrote about the Logos begotten of the Father: "So, my friends, I said, I shall now show from the Scriptures that God

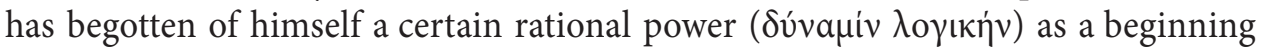

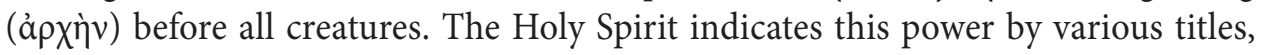
sometimes the Glory of the Lord (Exod 16:7), at other times Son (Ps 2:7), or Wisdom (Prov 8:22), or Angel, or God, or Lord, or Word. He even called himself Commander-in-chief (à $\rho \chi\llcorner\sigma \tau \rho \dot{\alpha} \tau \eta \gamma o v)$ when he appeared in human guise to Joshua, the son of

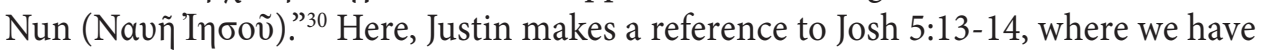
a description of Joshua's encounter with the commander of the Lord's army, who came with the sword to lead the Israelites further on. This commander of the Lord's

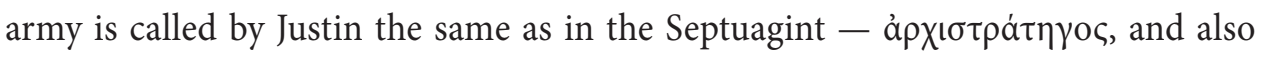

Cf. Scerbo, Dizionario, 67.

Josh 5,2 (Rahlfs, Septuaginta, 360).

Justin, Dialogue, 61,1 (Falls, 93-94; Marcovich, 175). 


\section{LESZEK MISIARCZYK}

the name of Joshua reappears in the form of Inooṽ s. In turn, in Dial. 62:5 Justin quotes the entire text that describes this event in Josh 5:13-6:2:

And it came to pass, when Joshua was near Jericho, he lifted up his eyes, and saw a man standing opposite him. And Joshua went to him and said: Are you one of our side, or of our opponents? And he answered: I am the prince of the host of the Lord, and now I am come. Joshua fell on his face to the ground, and said to him: Lord, what do you command your servant? And the Lord's prince said to Joshua: Take off your shoes, for the place on which you stand is holy. Now Jericho was shut down and fortified, and no one went out from it. And the Lord said to Joshua: Behold, I have given Jericho into your hands, and its king, and all its valiant men ${ }^{31}$

Again, what appears in the Greek text of the Dialogue, is the same terms as in

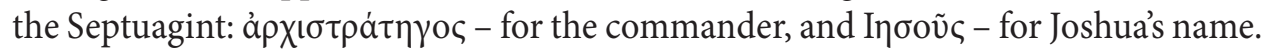
Justin does not interpret this passage typologically; however, in the figure of commander he notices the hidden revelation of the Logos, the Son of God preexisting in the times of the Old Testament, who led the Israelites into the Promised Land. It will be interesting, however, to compare the text from the Dialogue with the modern edition of the Septuagint, which clearly confirms that Justin did use this Hellenized version of the Scriptures.

\begin{tabular}{|c|c|}
\hline Dialogue $62: 5^{32}$ & LXX - Josh 5:13-14-6:2 $2^{33}$ \\
\hline 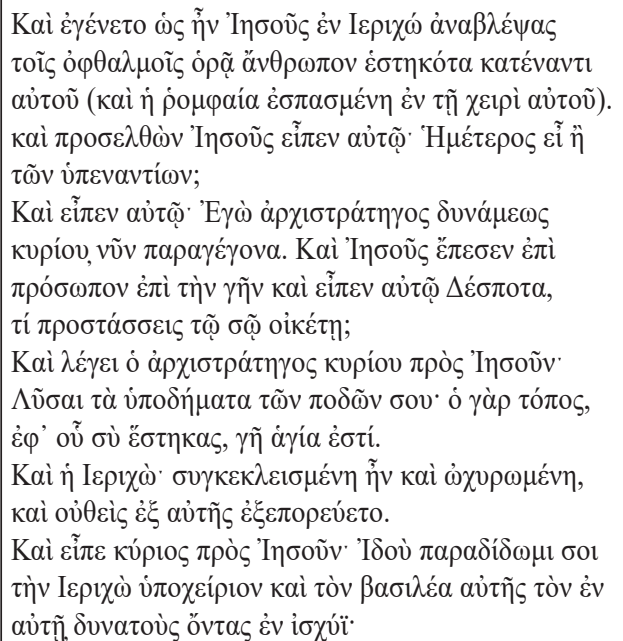 & 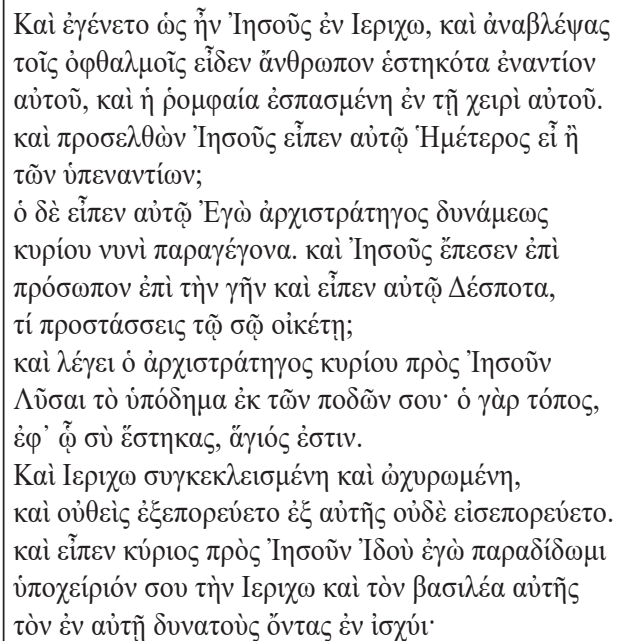 \\
\hline
\end{tabular}

31 Justin, Dialogue 62,5 (Falls, 96; Marcovich, 177-178).

32 Justin, Dialogue 62,5 (Marcovich, 177-178).

33 Rahlfs, Septuaginta, 361. 
In chapter 114, Justin presents the Old Testamentary presaging the sacrifice of Christ, which included Moses stretching out his hands in the shape of a cross during the fight against the Amalekites (Exod 17) or lifting up the serpent in the wilderness (Num 21). In turn, the blood of the Passover lamb (Exod 12) was a type of foreshadowing of Christ's Pascha, i.e., the salvation of mankind, which was to be accomplished through His blood. And here is an interesting passage from Dial. 111:4:

So, too, the red rope, which the spies sent by Joshua, son of Nun, gave to Rahab the harlot in Jericho, instructing her to tie it to the same window through which she lowered them down to escape their enemies, was a symbol of Christ's blood, by which those of every nationality who were once fornicators and sinful are redeemed, receiving pardon of their past $\sin$ and avoiding all sin in the future. ${ }^{34}$

In this text, apart from referring once again in Greek to Joshua, the son of Nun,

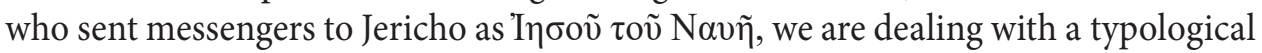
interpretation of the scarlet thread as a foreshadowing of the blood of Christ, which will be omitted by us, since it does not directly relate to our subject. In Dial. 132:1 Justin reproaches the Jews that they have crafted a golden calf, committed adultery with the daughters of Gentiles, and worshiped idols, even despite such miracles as "the sun stand in the heaven and not set for thirty-six hours at the command of him who was surnamed Jesus." ${ }^{35}$ However, we have here a reference to the historical situation, and again, only the name of Joshua appears in Greek as Inooṽ.

Joshua's typological interpretation resounds most fully in Dial. 113, where Justin introduces many new elements and explains those previously mentioned (c. 24). Particularly interesting to us is the following passage of Justin's text, which is worth quoting in its entirety.

Here is an example of what I am talking about. Jesus (Inбoṽv), as I said many times before, whose name had been Auses (Aủoñv), was named Jesus (Inбoṽv) by Moses when he was sent out as a spy with Caleb into the land of Canaan. Now, you are not curious to know why he did this, nor do you ask or investigate the reason. Hence, you have never discovered Christ, and when you read you fail to understand; when you hear us now telling you that Jesus is our Christ, you do not study the question to discover that he was given this name deliberately and not accidentally. Instead, you conduct a theological debate of the question why one "a" was added to Abraham's original name (Gen 17:5), and you seriously dispute why one " $r$ " was added to Sara's name (Gen 17:15). But why do you never inquire

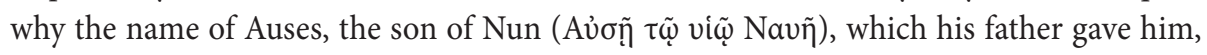
was changed to Jesus (Inбoṽ)? Especially since not only was his name changed, but also,

34 Justin, Dialogue 111,4 (Falls, 166-167; Marcovich, 261).

35 Justin, Dialogue 132,1 (Falls, 199; Marcovich, 298). 


\section{LESZEK MISIARCZYK}

after becoming Moses' successor, he alone, of all his contemporaries who fled Egypt, ${ }^{36}$ led the rest of the people into the Holy Land (Nm 32:11-12). And just as he, not Moses, conducted the people into the Holy Land and distributed it by lot among those who entered, so also will Jesus the Christ (Inбoṽ co Xpıбòৎ) gather together the dispersed people and distribute the good land to each, though not in the same manner. For, Joshua gave them an inheritance for a time only, since he was not Christ our God, nor the Son of God; but Jesus, after the holy resurrection, will give us an inheritance for eternity. Joshua indeed

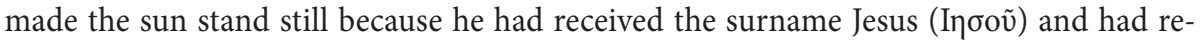

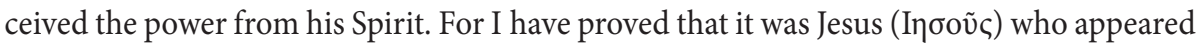
to and talked with Moses, Abraham, and, in short, with all the patriarchs, doing the will of the Father. He also became man by the Virgin Mary and lives forever. After his coming the Father will, through him, renew heaven and earth (Ap 21:1). This is he who is to shine in Jerusalem as an eternal light. This is he who is King of Salem and priest of the Most High forever according to the order of Melchisedek (Gen 14:18; Hb 5:6.10). Joshua is reputed to

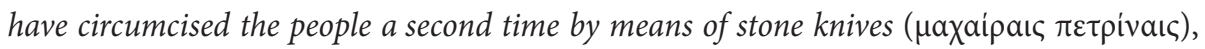

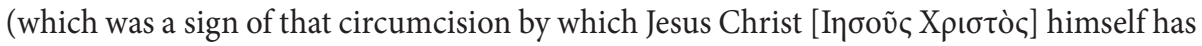
cut us off from idols made of stone and other materials), and to have gathered together those who everywhere from the uncircumcision, that is, from worldly error, were circumcised with stone knives, namely, the words of our Lord Jesus (Inбoṽ). For I have already pointed out that the prophets used to call him figuratively a Stone and a Rock. By the stone

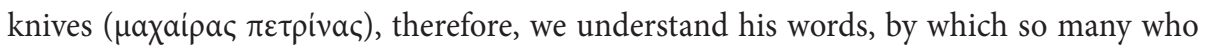
were in error have been circumcised from their uncircumcision with the circumcision of the heart. From that time God commanded through Jesus (Inбoṽ) that they who had the circumcision which began with Abraham should be circumcised again with the circumcision of the heart, for he said that Joshua (Inбoũv) performed a second circumcision

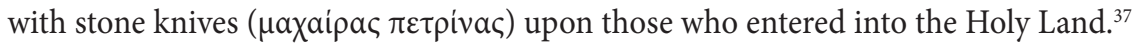

Justin begins his argumentation by recalling that Auses (Av̉oñv), along with Caleb, were chosen by Moses to explore the land of Canaan, and that Moses himself

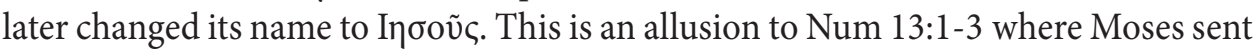
one leader from each tribe at God's command to explore the land of Canaan, the possession over which he intended to grant the sons of Israel. Among them was Hoshea

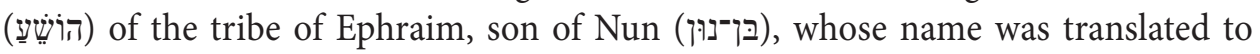

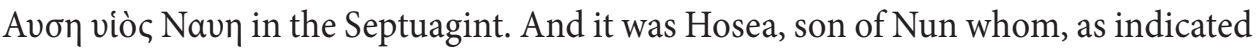

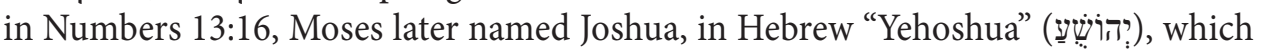
the Septuagint translates into Greek as Inбoṽv. Therefore, when Justin refers to Joshua as "Jesus," he does so on account of the translation in the Septuagint, as the Hebrew text contains a different version of it. With this, he is able to present a typological interpretation of Joshua and his deeds, basing it on the identical form of his name

36 To be precise, according to the Bible, also Caleb remained, but his name, or identity, was not changed.

37 Justyn, Dialog 113,1-7 (Falls, 168-170; Marcovich, 263-265). 


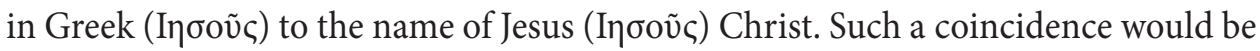
completely not understandable had he based his interpretation on the Hebrew text. In the further part of his argument, Justin criticizes Trypho for not considering why Moses changed Auses's (Hosea's) name to Joshua, hence failing to comprehend why Jesus is a Christ, i.e. the foretold Messiah, neither does he recognize that this name was not given to Him by chance. He criticizes his interlocutor for pondering the purpose of adding an additional "a" to the name of Abraham because he was previously called "Abram," and also a second "r" to the name of Sarrah, who was previously called "Sarah". However, he does not inquire with the same eagerness into why the name of Auses, the son of Nun given to him by his birth father, was changed to Jesus. Trypho adheres to the Rabbinic tradition because it was the rabbis who pondered the meaning of adding "a" to Abraham's name and "r" to Sarah's. ${ }^{38}$ Yet, one finds no reflection on the change of Auses's name to Joshua in the Rabbinic texts. Moreover, Justin emphasizes that Auses, apart from having his name changed to Joshua, also became the successor of Moses. He was the only one of the entire tribe of Israelites who left Egypt and brought into the Holy Land those who reached its borders (Num 32:11-12). Let us start with a remark that Justin is again inaccurate in stating that Joshua was the only one to enter the Promised Land, as Caleb, according to the biblical text, also entered it. Aside from the change of name, the Apologist stresses the fact that Joshua became the successor of Moses, in whose stead he was to lead the chosen people to the new land. Justin, admittedly, did not explicitly write that, but it can be surmised from the context that the change of Ausesa's name to Joshua took place because he was supposed to replace Moses as leader of the Israelites, guiding them to the Promised Land and dividing the land among those who reached it. Further on, he clearly presents Joshua and his deeds as the type of Christ and His actions. Just as Joshua brought the people into the Promised Land and divided it among them, thereby giving them a temporal inheritance, Jesus Christ brings the scattered people back into eternal life. Joshua stopped the sun (Josh 10:12-13) only after his name had been changed, having received this power from the Spirit of Jesus Christ, who was already active in the times of the Old Testament. Subsequently, Justin mentions his earlier argument that it was none other than Jesus, the pre-existing son of God, who appeared according to the will of the Father to Moses, Abraham and all other patriarchs and became a man from Virgin Mary without ceasing to be God at the same time. Through Him the Father wants to renew Heaven and Earth, and he will shine as an everlasting light in Jerusalem. Further, he revisits the story of Joshua to interpret typologically not only his person but also the second circumcision of the people, flint knives and a pile of stones in Gilgal. Let us start with the analysis of the first element, that is, the second circumcision, which proves to be more complicated than it seems at first glance. On the one hand, we read in the Hebrew

Cf. e.g. Midrash Rabbah to the Book of Genesis. 
Bible that God instructed Joshua to: "Make flint knives and circumcise the people of

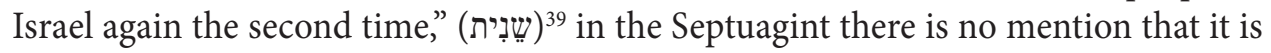
a second circumcision: "He will prepare flint knives of sharp cut stone ( $\mu$ axaipac

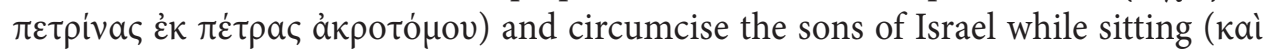

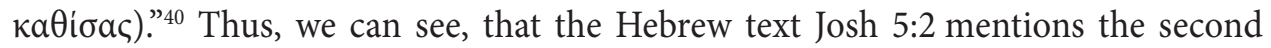
circumcision of the sons of Israel and nothing about sitting, in turn the Septuagint omits the mention of the second/repeated circumcision and adds the element of the sitting position. Most likely the author of the Greek translation confused the Hebrew $\check{s} b$ derived from $\check{s} w b$ which means "do again/repeat" with $\check{s} b$ derived from $y \check{s} b$ which means "sit." Adding the phrase "a second time" (שָנית) at the end of the verse in the Hebrew text suggests that $s ̌ b$ is to be read as "do again" rather than "sit." The most interesting fact, however, is that in the Septuagint (Codex Alexandrinus) we find both "sit" and "for a second time,"41 although Rahlfs in his critical edition of the Septuagint, in the critical apparatus, marks only "a second time" ( $\varepsilon \kappa \delta \varepsilon v \tau \varepsilon \dot{\varepsilon} \rho o v)$ as a version present in Alexandrinus. In any case, Codex Alexandrinus confirms that the version in Josh 5:2 in Greek is exactly the same as the Hebrew text containing "a second time/again" ( $\varepsilon \kappa \delta \varepsilon v \tau \varepsilon \dot{\rho} \rho 0 v)$. Because in Dial. 113:6 Justin also wrote about the "second" ( $\delta \varepsilon v \tau \dot{\varepsilon} \rho a v)$ circumcision of the people, which Joshua was to perform after the Israelites entered the promised land, he would be the oldest witness to the version that later appeared in the Codex Alexandrinus. Because Justin did not know Hebrew, it seems unlikely that he used the Hebrew text at this point. Therefore, it appears that he was using the Greek version of Septuagint which included the phrase "a second time." Marcovich (p. 265) in his critical edition of Justin's Dialogue unnecessarily marks this $\delta \varepsilon v \tau \varepsilon \dot{\rho} \rho \alpha$ as a quotation, most probably influenced by Rhalfs' critical edition. Unfortunately, he did not look into the critical apparatus in which Rhalfs clearly shows that Codex Alexandrinus contains the Septuagint version with $\varepsilon \kappa \delta \varepsilon v \tau \varepsilon$ é referred to by Justin. Therefore, the Apologist bases his interpretation of Josh 5:2 not only on the Septuagint but also on the ancient version later confirmed by Codex Alexandrinus. Assuming that the second circumcision version is sufficiently well-documented textually, how should it be interpreted? It is hard to imagine that the text is meant to repeat circumcision in the literal sense. Moreover, the Hebrew text itself explains further that this repeated circumcision applied to those Israelites who had already been born in the wilderness and they had not yet been circumcised at all, and this was their first circumcision. So why it is used here the phrase "for the second time"? The term "a second time" would therefore mean performing circumcision "again/once more" on the sons of Israel who were born during a desert trek and were

39 A quote from the New Revised Standard Version. Hebrew terminology according to Biblia Hebraica Stuttgartensia.

40 Rahlfs, Septuaginta, 360.

41 In the above analyses I base on Graeme Auld, Joshua, 123. 
uncircumcised. Justin, on the other hand, uses this element to show that the repeated circumcision of the people that Joshua performed after entering the promised land was a type and foreshadowing of the circumcision from stones, i.e., other pagan deities and the error of the world by teaching Gentiles the worship of the true God with which Jesus Christ was to sever those believing in him. According to him, it was Christ who made not one pile out of twelve stones, like Joshua in Gilgal, but whole piles of the uncircumcised, that is, the Gentiles, who would be circumcised with the new flint knives, that is, with His words. Since Christ was foretold by the prophets, among others in Dan 2 as a rock or a stone, then, Justin repeats, stone knives

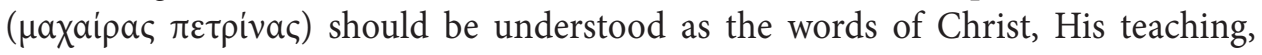
thanks to which a great number of strayed, uncircumcised people were severed from the error of polytheism and false gods. According to Justin, God encouraged such circumcision of the heart by Joshua also for those who had already received carnal circumcision from Abraham, when it is said that Joshua circumcised those who en-

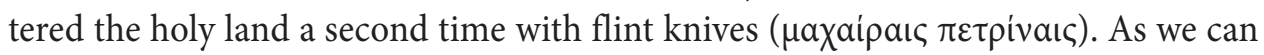
see, in the typological interpretation of the second circumcision, Justin deviates from the Hebrew text, in which the author explains that it was about the circumcision of men who were born in the desert and had not been circumcised. For Justin, this second circumcision is a spiritual circumcision accomplished by the teachings and words of Christ, which should be believed.

As we have seen, Justin clearly portrays Joshua as a type of Jesus Christ, his circumcision of the Israelites as a type of heart circumcision which Christ performs on those who believe in Him, the pile of twelve stones that Joshua placed at Gilgal in memory of that circumcision is a type of many piles of Gentiles severed from stones, that is, pagan deities and the error of the world, and Joshua's flint knives are a type of Jesus' words and His teaching with which the heart circumcision is performed. The typological interpretation of Joshua and the stone knives was only possible because Justin used the Hellenized version of the Old Testament, the Septuagint, using

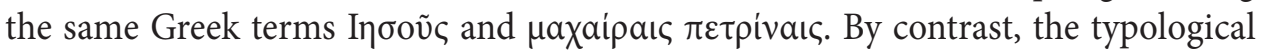
interpretation of "second/repeated circumcision" is based on the version of the Septuagint that contained the phrase $\varepsilon \kappa \delta \varepsilon v \tau \varepsilon \dot{\rho} \rho 0 v$ later confirmed by Codex Alexandrinus.

Translated by Grzegorz Knyś

\section{Bibliography}

\section{Sources}

Ellinger, K. - Kittel, R. (eds.) Biblia Hebraica Stuttgartensia (Stuttgartt: Deutsche Bibelgesellschaft 1990).

Graeme Auld, A., Joshua. Jesusm son of Naue in Codex Vaticanus (Leiden - Boston, MA: Brill 2005). 


\section{LESZEK MISIARCZYK}

Justin Martyr, Iustini Martyris Dialogus cum Tryphone (ed. M. Marcovich) (Patristische Texte und Studien 47; Berlin - New York: De Gruyter 1997); English trans. T.B. Falls: Dialogue with Trypho (revised by T.P. Halton; ed M. Slusser) (Washington, D.C.: Catholic University of America Press 2003).

Rahlfs, A. (ed.), Septuaginta (Stuttgart: Deutsche Bibelgesellschaft 1979).

\section{Studies}

Andresen, C., "Justin und der mittlere Platonismus", Zeitschrift für Neutesamentliche Wissenschaft 44 (1952-1953) 157-195.

Barnard, L.W., Justin Martyr. His Life and Thought (Cambridge: Cambridge University Press 1966).

Barrett, C.K., "Jews and Judaizers in the Epistles of Ignatius", Jews, Greeks and Christians. Religious Cultures in Late Antiquity. Essays in Honor of W. D. Davies (eds. R. Hamerton-Kelley - R. Scroggs) (Leiden: Brill 1976) 220-224.

Barthélemy, D., Les devanciers d'Aquila (Leiden: Brill 1963).

Bokser, B.Z., "Justin Martyr and the Jews," Jewish Quarterly Review 64 (1973-1974) 97-122, 204-211.

Bokser, B.Z., "Recent Developments in the Study of Judaism. 70-200 C.E.," Second Century 3 (1983) 1-68.

Bons, E. - Pouchelle, P. - Scialabba, D., The Vocabulary of the Septuagint and Its Hellenistic Background (Tübingen: Mohr Siebeck 2019).

Bourgeois, D., La sagesse des anciens dans le mystère du Verbe. Évangile et philosophie chez saint Justin (Paris: Téqui 1981).

Callan, T., Forgetting the Root. The Emergence of Christianity from Judaism (New York: Paulist Press 1986).

Cantalamessa, R., "Cristianesimo primitivo e filosofia greca," Il cristianesimo e le filosofie, (ed. R. Cantalamessa) (Milano: Universita del Sacro Cuore1971) 26-57.

Chadwick, H., Early Christian Thought and the Classical Tradition. Studies to Justin, Clement and Origen (Oxford: Oxford University Press 1966).

Chadwick, H., "Justin Martyr's Defense of Christianity", Bulletin of the John Rylands Library 47/2 (1965) 275-297.

Constantelos, D.J., "Jews and Judaism in the Early Greek Fathers (A.D. 100-500)," Studies in Early Christianity (ed. E. Ferguson) (New York - London: Eerdmans 1993) IX, 273-294.

Cook, J. - Stripp, H.-J. (eds.), Text-Critical and Hermeneutical Studies in the Septuagint (Leiden Boston, MA - Köln: Brill 2012).

Daniélou, J., Études dexégèse judéo-chrétienne (Les testimonia) (Paris: Beauchesne 1966). Daniélou, J., Message évangelique et culture hellénistique au IIe et IIIe siècle (Tournai: Desclée 1961).

Fernández Marcos, N., The Septuagint in Context. Introduction to the Greek Versions of the Bible (Leiden - Boston, MA - Köln: Brill 2000).

Frend, W.H.C., "Early Christianity and Society: A Jewish Legacy in the Pre-Constantinian Era," Harvard Theological Review 76 (1983) 53-71.

Goodenough, E.R., The Theology of Justin Martyr (Jena: Frommann 1923), Reprint (Amsterdam: Philo 1968). 


\section{INFLUENCE OF THE SEPTUAGINT ON THE TYPOLOGICAL INTERPRETATION}

von Harnack, A., Die «Altercatio Simonis Iudaei et Theophili christiani» nebst Untersuchungen über die antijüdische Polemik in der alten Kirche (Leipzig: Hinrichs 1883).

von Harnack, A., Judentum und Judenchristentum in Justins Dialog mit Trypho (Texte und Untersuchungen zur Geschichte der altchristlichen Literatur 39; Berlin: Hinrichs 1913).

Herford, R.T., Christianity in Talmud and Midrash (Clifton, NJ: Reference Book 1966).

Holte, R., "Logos Spermatikos. Christianity and Ancient Philosophy according to St. Justin's Apologies", Studia Theologica 12 (1958) 109-168.

Hyldahl, N., Philosophie und Christentum. Eine Interpretation der Einleitung zum Dialog Justins (Kopenhagen: Prostant apud Munksgaard 1966).

Jaeger, W., Wczesne chrześcijaństwo i grecka "Paideia" (Bydgoszcz: Homini 1997).

Joly, R., Christianisme et philosophie. Études sur Justin et les Apologistes grecs du duxieme siécle (Bruxelles:Éditions de l'Université de Bruxelles 1973).

Lieu, J. et al. (eds.), The Jews Among Pagans and Christians in the Roman Empire (LondonNew York: Routledge 1992).

Karłowicz, D., Sokrates i inni święci (Warszawa: Fronda 2005).

Krauss, S., "The Jews in the Works of the Church Fathers," Studies in Early Christianity (ed. E. Ferguson) (New York - London: Eerdmans 1993) VI, 219-230.

Meeks, W.A. - Wilken, R.L., Jews and Christians in Antioch in the First Four Centuries of the Common Era, (Missoula, MT 1978).

Misiarczyk, L., “Apologetyka wczesnochrześcijańska," Pierwsi apologeci greccy (trans. L. Misiarczyk) (Kraków: Wydawnictwo M 2004) 15-48.

Misiarczyk, L., “Teologia dziejów w pismach św. Justyna," Studia Antiquitatis Christianae 15 (2001) 146-160.

Misiarczyk, L., "Wstęp," Justyn Męczennik, 1 i 2 Apologia. Dialog z Żydem Tryfonem (ed. L. Misiarczyk) (Warszawa: Wydawnictwo Naukowe UKSW 2012) 123-150.

Misiarczyk, L., Il Midrash nel Dialogo con Trifone di Giustino Martire, (Płock: Płocki Instytut Wydawniczy 1999). Nichols, W., Christian Antisemitism (Northvale, NJ: Rowman \& Littlefield 1992). Otranto, G., Esegesi biblica e storia in Giustino (Dial. 63-84) (Bari: Istituto di letteratura cristiana antica, Università 1979).

des Places, É., "Platonisme moyen et apologétique chrétienne au IIe siecle aprés Numénius, Atticus, Justin", Studia Patristica (ed. E.A. Livingston) (Texte und Untersuchungen 128; Berlin: Akademie-Verlag 1984) XV, 432-441.

Pycke, N., "Connaissaince rationnelle et conaissance de grâce chez saint Justin," Ephemeredies Theologicae Lovanienses 37 (1961) 52-85.

Radford Ruether, R., "The Adversus Judaeos Tradition in the Church Fathers: the Exegesis of Christian anti-Judaism," Essential Papers on Judaism and Christianity in Conflict (ed. J. Cohn) (New York: New York University Press 1991) 174-187.

Remus, H., "Justin Martyr's Argument with Judaism", Anti-Judaism in Early Christianity (ed. S.G. Wilson) (Waterloo: Wilfrid Laurier University Press 1986) II, 59-80.

Rendel Harris, J., Testimonies (Cambridge: Cambridge University Press 1916-1920) I-II. Rokeah, D., Jews, Pagans and Christians in Conflict (Jerusalem: Hebrew University - Leiden: Brill 1982). Sanders, E.P. (ed.), Jewish and Christian Self-Definition (Philadelphia, PA: Fortress 1980-1982) I-II. 


\section{LESZEK MISIARCZYK}

Schmid, W., Frühe Apologetik und Platonismus. Ein Beitrag zur Interpretation des Proöms von Justins Dialogus (Heidelberg: Winter Universitätsverlag 1952). Scerbo, F., Dizionario Ebraico e Caldaico del Vecchio Testamento (Firenze: Libreria Editrice Fiorentina 1912).

Schneider, H.P., "Some Reflections on the Dialogue of Justin Martyr with Trypho," Scottish Journal of Theology 15 (1962) 164-175.

Setzer, C., Jewish Responses to Early Christians. History and Polemics 30-150 C.E. (Assen - Minneapolis, MN: Fortress 1994).

Shotwell, W.A., The Biblical Exegesis of Justin Martyr (London: SPCK 1965).

Simon, M., "La Bible dans les premières controverses entre Juifs et chrétiens," Le monde grec ancien de la Bible (ed. C. Mondésert) (Paris: Beauchesne 1984) 107-125.

Simon, M., Verus Israel. Études sur les relations entre chrétiens et juifs dans l'Empire Romain (135-425) (Paris: Boccard 1964).

Skarsaune, O., “The Conversion of Justin Martyr," Studia Teologica 30 (1976) 53-73.

Skarsaune, O., The Proof from Prophecy. A Study in Justin Martyr's Proof-Text Tradition. TextType, Provenance, Theological Profile (Oslo [s.n.]: 1982).

Smit Sibinga, J., The Old Testament Text of Justin Martyr. I. The Pentateuch (Leiden: Brill 1963). Stanton, G.N., "Aspects of Early Christian-Jewish Polemic and Apologetic," New Testament Studies 31 (1985) 377-392.

Stern, M., Greek and Latin Authors on Jews and Judaism (Jerusalem 1974-1984) I-III.

Tränkle, H., Q.S.F. Tertulliani Adversus Iudaeos (Wiesbaden: Steiner 1964).

Van den Winden, J.C.M., An Early Christian Philosopher. Justin Martyr's Dialogue with Trypho. Chapter One to Nine (Leiden: Brill 1971).

Veltri, G., Eine Tora für den König Talmai (Tübingen: Mohr 1994).

de Vogel, J.C., "Problems Concerning Justin Martyr. Did Justin find a Certain Continuity between Greek Philosophy and Christian Faith?", Mnemosyne 31 (1978) 360-388.

Tylor, M.S., Anti-Judaism and Early Christian Identity (Leiden: Brill 1994). 